\section{Pengaruh Kualitas Situs Website, Kepercayaan Konsumen, Dan Pengalaman Berbelanja Terhadap Minat Beli Ulang Di Situs Jual Beli Online OLX}

\author{
Rangga Dwigana Hariadi dan Sulistiono \\ Program Studi Manajemen, Institut Bisnis dan Informatika Kesatuan \\ E-Mail: rangga.dwigana@ibik.ac.id
}

\section{Website and Online \\ Repurchasing \\ Interest}

Submitted: SEPTEMBER 2020

Accepted: JULI 2021

\begin{abstract}
OLX Indonesia is a free electronic commerce site that advertises services for sellers, where there are no fees for conducting transactions either selling or buying. Not only that, OLX Indonesia can also be search engine friendly because not only site visitors can find published advertisements, but also people who search for products and services through search engines. The purpose of this study is to 1) To find out and analyze the influence of Website Quality, Consumer Trust and Shopping Experience Together on Repurchase Interest on Olx Online Buying and Selling Sites. 2) To find out and analyze the influence of Website Quality on Repurchase Interest on Olx Online Buy and Sell Sites. 3) To Know and Analyze the influence of Consumer Trust on Repurchase Interest on the Olx Online Buy and Sell Site. 4) To find out and analyze the effect of the Shopping Experience on Repurchase Interest on the Olx Online Buy and Sell Site. The number of respondents in this study amounted to 100 respondents taken from the City of Bogor. Research data were processed using SPSS. The results of this study are as follows: 1) Website Quality The website does not have a positive and significant effect on repurchase interest with a regression coefficient of 1.056 and has a significant value of 0.294. 2) Consumer Confidence A positive and significant effect on repurchase interest with a regression coefficient of 2.140 and has a significant value of 0.035. 3) Shopping Experience has a positive and significant effect on repurchase interest with a regression coefficient of 4.115 and has a significant value of 0.000. 4) Website Quality, Consumer Trust, and Shopping Experience have a positive and significant effect on Repurchase Interest on OLX Online Buying and Selling Sites with a calculated $F$ value of 25.978 and has a significance value of 0,000 .
\end{abstract}

Keywords: website quality, consumer belief, and shopping experience against repurchase interest

\begin{abstract}
ABSTRAK
OLX Indonesia merupakan situs perdagangan elektronik pasang iklan gratis yang merupakan layanan yang disediakan untuk para penjual, dimana dalam melakukan transaksi baik jual ataupun beli tidak dikenakan biaya. Tidak hanya itu, OLX Indonesia juga dapat menjadi search engine yang friendly karena bukan hanya pengunjung situs yang dapat menemukan iklan yang dipublikasikan, tetapi juga orang-orang yang mencari produk dan jasa melalui search engine. Maksud dari penelitian ini adalah untuk 1) Untuk Mengetahui dan Menganalisis pengaruh Kualitas Situs Website, Kepercayaan Konsumen dan Pengalaman Berbelanja secara Bersama-sama terhadap Minat Beli Ulang di Situs Jual Beli Online Olx. 2) Untuk Mengetahui dan Menganalisis pengaruh Kualitas Situs Website terhadap Minat Beli Ulang di Situs Jual Beli Online Olx. 3) Untuk Mengetahui dan Menganalisis pengaruh Kepercayaan Konsumen terhadap Minat Beli Ulang di Situs Jual Beli Online Olx. 4) Untuk Mengetahui dan Menganalisis pengaruh Pengalaman Berbelanja terhadap Minat Beli Ulang di Situs Jual Beli Online Olx. Jumlah responden dalam penelitian ini berjumlah 100 responden yang diambil dari Masyarakat Kota Bogor. Data penelitian diolah menggunakan SPSS. Hasil dari penelitian ini adalah sebagai berikut: 1) Kualitas Situs Website tidak berpengaruh positif dan tidak signifikan terhadap minat beli ulang dengan nilai koefisien regresi sebesar 1,056 dan memiliki nilai signifikan
\end{abstract}

\section{JIKES} Kesatuan Vol. 1 No. 1,2021 page. $1-12$ IBI Kesatuan
ISSN xxxx - xxxx DOI: $10.37641 /$ jikes.v1i1.402 
Website and Online Purchasing Interest sebesar 0,294. 2) Kepercayaan Konsumen Berpengaruh positif dan signifikan terhadap minat beli ulang dengan nilai koefisien regresi sebesar 2,140 dan memiliki nilai signifikan sebesar 0,035. 3) Pengalaman Berbelanja berpengaruh positif dan signifikan terhadap minat beli ulang dengan nilai koefisien regresi sebesar 4,115 dan memiliki nilai signifikan 0,000. 4) Kualitas Situs Website, Kepercayaan Konsumen, dan Pengalaman Berbelanja berpengaruh positif dan signifikan terhadap Minat Beli Ulang Pada Situs Jual Beli Online OLX dengan nilai F hitung sebesar 25,978 dan memiliki nilai signifikansi sebesar 0,000.

Kata Kunci: kualitas website, kepercayaan konsumen, pengalaman berbelanja, minat beli ulang

\section{PENDAHULUAN}

Perkembangan teknologi informasi yang semakin berkembang memberikan sebuah jaringan bisnis dunia yang tanpa batas. Penggunaan internet tidak hanya terbatas pada pemanfaatan informasi yang dapat diakses melalui media, melainkan juga dapat digunakan sebagai sarana untuk melakukan transaksi perdagangan dengan e-commerce dan sebuah jaringan bisnis dunia yang luas yang tidak terbatas waktu dan tempat. Menurut data yang dikeluarkan oleh Kementerian Komunikasi dan Informatika jumlah pengguna Internet di Indonesia pada tahun 2015 sudah mencapai 93,4 juta jiwa dengan 7,4 juta konsumen online dan dengan nilai transaksi mencapai US $\$ 3,65$ Miliar. Pada tahun 2016 diperkirakan ada 8,7 juta konsumen toko online dengan nilai transaksi US\$ 4,89 miliar dan diproyeksikan akan terus meningkat secara signifikan pada tahun yang akan mendatang. Tingginya jumlah pengguna internet, telah menarik berbagai usaha bisnis dengan menyediakan atau membuat toko online. Indonesia adalah salah satu negara yang trend dengan toko online atau online shop, hal ini dapat dilihat mulai bermunculan banyaknya toko online atau online shopping seperti Kaskus.co.id, Olx.co.id, Lazada.com, Bukalapak.com, Traveloka, Shopee dan masih banyak lagi, yang bisa ditemukan dengan mudah sesuai kategori yang akan dicari.

Saat ini banyak pebisnis berlomba memanfaatkan internet dalam mempromosikan maupun melakukan kegiatan jual beli barang yang dijualnya, yang biasa di sebut $E$ Commerce. Selain itu, di platform online seperti OLX Indonesia, barang bekas mempunyai perputaran yang cepat, barang paling laris pada industri ini di Indonesia yaitu fashion, gadget, dan tiket perjalanan. Sedangkan produk-produk elektronik di luar gadget, terutama rumah tangga berpotensi mengalami pertumbuhan. OLX Indonesia merupakan situs perdagangan elektronik pasang iklan gratis yang merupakan layanan yang disediakan untuk para penjual, dimana dalam melakukan transaksi baik jual ataupun beli tidak dikenakan biaya. Tidak hanya itu, OLX Indonesia juga dapat menjadi search engine yang friendly karena bukan hanya pengunjung situs yang dapat menemukan iklan yang dipublikasikan, tetapi juga orang-orang yang mencari produk dan jasa melalui search engine. OLX Indonesia yang merupakan merger antara Tokobagus.com dan Berniaga.com pada tahun 2015 adalah situs web iklan baris di Indonesia yang berfokus sebagai tempat membeli dan menjual produk serta jasa secara daring, yang merupakan platform untuk mencari barang baru maupun bekas berkualitas diantaranya produk otomotif, elektronik, peralatan rumah tangga , rumah, lowongan kerja, dan juga aneka jasa.

Banyaknya situs belanja online di Indonesia akan mengakibatkan potensi terjadinya kejahatan dalam internet, hal inilah yang menjadi masalah dalam berjalannya sistem $e$ commerce. Dengan adanya kejahatan online, masa depan e-commerce bergantung atas kepercayaan konsumen pada sebuah retailer web dan terhadap teknologi internet. Kepercayaan konsumen merupakan keyakinan oleh salah satu pihak yang diyakini akan memenuhi komitmennya oleh pihak lain (Gefen, 2003), Perkembangan ke depannya, $e$ commerce memiliki ketergantungan pada kepercayaan konsumen atas retailer web dan teknologi internet, dan nama baik penjual. Lebih lanjut, kondisi tersebut diatas 
berimplikasi pada ketergantungan pembeli online pada informasi elektronik tanpa dapat memeriksa langsung informasi fisiknya. Berlangsungnya e-commerce sangat penting dengan adanya kepercayaan (trust) karena merupakan dasar bagi transaksi penjual dan pembeli yang membuat konsumen berharap terciptanya kepuasan dari hubungan tukar menukar tersebut (Pavlou, 2003)

Fenomena pada penelitian ini adalah OLX Indonesia menghadirkan fitur dan tampilan OLX Indonesia di aplikasi mobile, sementara untuk versi Web (desktop dan mobile) masih tetap menggunakan tampilan lama untuk memastikan proses transisi berjalan lancar. Adanya pengguna internet masih kesulitan dalam melakukan belanja omline, hal ini karena dalam website OLX Indonesia tidak ada fitur komentar di lapak para penjual sehingga mempersulit pembeli untuk memastikan apakah penjual tersebut kredibel atau tidak hal ini terkait dengan variabel pengalaman berbelanja. Dalam OLX Indonesia tidak di lengkapi fitur pembayaran yang dapat dilakukan langsung dalam aplikasi, pembayaran dapat dilakukan dengan secara langsung bertemu antara penjual dan pembeli dengan sitem COD (cash on delivery) sehingga dapat meningkatkan kepercayaan konsumen dan mengurangi kejahatan dalam berbelanja online. Kebanyakan pengguna mengeluhkan tidak adanya nomor ponsel penjual sebagai metode komunikasi yang kini diganti dengan fitur chat.

Apakah anda mengetahui fitur pemberian informasi yang disediakan oleh OLX?

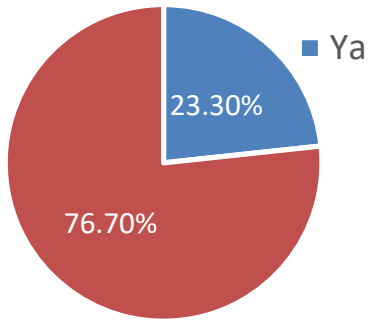

Ketika petugas sedang melayani permohonan apakah masalah yang dialami pengguna diselesaikan pada saat itu juga?

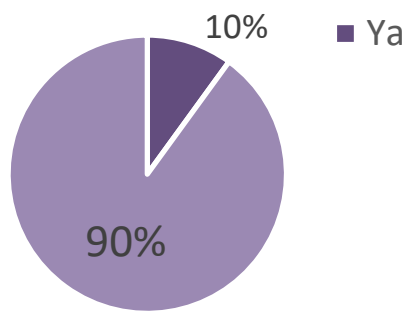

Gambar 1. Data Responden Survey Pendahuluan Fitur Pemberian Informasi Sumber: Data Primer Diolah

Dilihat dari hasil survey pendahuluan bahwa $76,70 \%$ responden yang tidak mengetahui adanya fitur pemberitahuan informasi yang disediakan OLX terhadap responden. Dari variabel Kualitas Situs Website dapat disimpulkan terjadi masalah saat petugas memberikan pelayanan kepada pelanggan yang menggunakan aplikasi OLX. Responden sebanyak 90\% yang tidak mengetahui permohonan tanggapan pengguna OLX diselesaikan secara tepat waktu atau tidak. Sehingga berpengaruh terhadap variabel kepercayaan konsumen. Karena penggunaan aplikasi jual beli online semakin tinggi, maka pihak manajemen OLX dapat segera meningkatkan kulitas website yang mudah digunakan oleh konsumen. Dalam memberikan layanan kepercayaan terhadap konsumen dengan memberikan garansi atas uang yang telah di bayarkan oleh konsumen melalui pembayaran yang telah disediakan sehingga dapat terciptanya pengalaman yang puas pada konsumen agar terwujudya sifat minat beli.

Berdasarkan latar belakang dan Rumusan masalah yang dituturkan diatas, maka tujuan penelitian ini adalah untuk Mengetahui dan Menganalisis pengaruh Kualitas Situs Website, Kepercayaan Konsumen dan Pengalaman Berbelanja secara parsial dan secara bersama-sama terhadap Minat Beli Ulang di Situs Jual Beli Online OLX.

\section{Pengembangan Hipotesis}

Liang dan Chen (2009) mempelajari pengaruh kualitas situs pada kinerja hubungan pelanggan membuktikan bahwa mampu menarik niat pembelian kembali di antara pelanggan. Christina (2012) ia berpendapat, kepercayaan berperan penting dalam pembelian melalui media online. Karena tidak adanya tatap muka maka kepercayaan 
Website and

Online Purchasing

Interest

menyebabkan niat pembelian kembali pelanggan. Di sisi lain, Lin (2007) mengemukakan pengaruh dimensi kualitas situs web pada kepuasan pelanggan dalam konteks B2C ecommerce juga berpengaruh signifikan dengan niat pembelian kembali pelanggan. selanjutnya, Liang dan Chen (2009) mempelajari pengaruh kualitas situs pada kinerja hubungan pelanggan membuktikan bahwa mampu menarik niat pembelian kembali di antara pelanggan. Berdasarkan penelitian yang dilakukan Yuliandi (2012), yang berjudul "Pengaruh Kualitas Website Terhadap Minat Beli Produk Jaben Bandung", menghasilkan temuan bahwa kualitas website (informasi, interaksi, dan usability), variable usability website berpengaruh positif dan signifikan terhadap minat beli ulang. Hipotesis 2: Kualitas Situs Website (X1) tidak berpengaruh positif terhadap Minat Beli Ulang (Y).

Christina (2012) ia berpendapat, kepercayaan berperan penting dalam pembelian melalui media online. Karena tidak adanya tatap muka maka kepercayaan yang konsumen dapatkan terhadap penjual atau sebuah situs online menjadi hal utama. Kejujuran pemilik online shop dalam menjaga dan memenuhi kesepakatan yang telah dibuat baik berdasarkan reputasi online shop sebagai penjual yang kredibel maupun tampilan promosi secara professional yang mengindikasikan bahwa toko maya tersebut berkompeten dalam menjalankan operasionalnya dan akan berkaitan dengan minat konsumen. Hanya konsumen yang memiliki kepercayaan yang mau melakukan transaksi secara online, tanpa adanya kepercayaan mustahil transaksi e-commerceakan terjadi. Berdasarkan penelitian yang dilakukan Tika (2014) dengan judul "Pengaruh Harga, Promosi, Kualitas Produk, dan Kepercayaan Konsumen terhadap Minat Beli K-Pop (Korean Pop) Album Dengan Sistem Pre-order Secara Online (Studi Pada Online Shop Kordo Day Shop (CORP) Semarang. Penelitian ini menggunakan analisis linier berganda dengan hasil kepercayaan konsumen berpengaruh signifikan positif terhadap Minat beli ulang. Hipotesis 3: Kepercayaan Konsumen (X2) berpengaruh positif terhadap Minat Beli Ulang (Y).

Ling (2010) berpendapat bahwa konsumen dengan niat berbelanja online yang kuat pada situs jual beli online biasanya telah memiliki pengalaman pembelian sebelumnya yang membantu mereka mengurangi rasa ketidak pastiannya. Konsumen dapat memperoleh pengalaman dengan melakukan pembelian kecil pada awalnya, setelah itu mereka akan lebih mengembangkan kepercayaan diri dalam melakukan belanja online. Jika pengalaman yang diterima konsumen ternyata memberikan rasa kepuasan dalam berbelanja online, maka akan meningkatkan minat belinya dan akan membuat konsumen melakukannya lagi di masa depan serta akan merekomendasikannya kepada orang lain. Namun, jika pengalaman negatif yang diterimanya saat berbelanja online, maka pelanggan akan enggan untuk melakukannya lagi di masa depan. Berdasarkan penelitian yang dilakukan Yustinus Frandhi Cahyo Pamungkas (2014) dengan judul "Pengaruh Orientasi Pembelian, Kepercayaan, Dan Pengalaman Pembelian Online Terhadap Minat Beli Online". Hasil penelitian menyebutkan bahwa variabel orientasi pembelian impulsif, orientasi merek, orientasi kualitas, kepercayaan dan pengalaman pembelian berpengaruh signifikan terhadap pembelian online.Oleh karena itu, Pengalaman Berbelanja 
mempengaruhi Minat beli ulang. Hipotesis 4: Pengalaman Berbelanja (X3) berpengaruh positif terhadap Minat Beli Ulang (Y).

\section{METODE PENELITIAN}

Penelitian ini dilakukan di Kota Bogor untuk mendapatkan responden yang akan menjawab kuesioner yang dibagikan. Penelitian ini dilakukan selama dua bulan mulai Maret sampai dengan April 2020. Dalam pengumpulan data dan informasi yang diperlukan dalam penelitian ini, penulis memperoleh data informasi yang bersumber dari: (1) Data Primer, yaitu data yang diperoleh secara langsung dari sumbernya melalui pembagian kuesioner kepada responden, dengan melakukan penyebaran kuesioner maka diperoleh data primer yaitu data mengenai identitas dan karakteristik responden, dan data mengenai persepsi responden. Data mengenai karakteristik atau identitas responden yang meliputi jenis kelamin, usia, pekerjaan, pendidikan, pendapatan, dan pengeluaran. Adapun persepsi responden merupakan jawaban responden mengenai variabel penelitian, yaitu kualitas situs website, kepercayaan konsumen, pengalaman berbelanja, dan minat beli konsumen. Dengan diperoleh data primer tersebut sehingga peneliti merupakan tangan pertama yang memperoleh data tersebut. (2) Data Sekunder, merupakan data yang telah dikumpulkan dan diolah lebih lanjut oleh lembaga pengumpul data dan dipublikasikan kepada masyarakat penggguna data. Selain itu, data sekunder juga dapat diperoleh melalui studi kepustakaan dan mempelajari literatur yang berhubungan dengan permasalahan yang sedang diteliti.

Populasi dalam penelitian ini adalah pengguna situs jual beli online Olx yang ada di Kota Bogor yang jumlahnya belum terindentifikasi oleh peneliti. Sampel pada penelitian ini adalah masyarakat berumur 15-75 tahun lebih orang yang menggunakan situs jual beli online OLX Indonesia di Kota Bogor. Dikarenakan populasi yang sangat besar dan peneliti tidak memungkinkan untuk mempelajari semua yang ada di populasi karena berbagai keterbatasan maka peneliti menggunakan sampel yang diambil dari populasi yang telah ditetapkan. Peneliti memutuskan untuk menetapkan jumlah responden sebanyak 100 orang sebagai sampel penelitian, penarikan sampel bertujuan untuk menentukan batasan bagi populasi yang diteliti.

Metode pengumpulan data pada penelitian ini menggunakan kuesioner, yaitu teknik pengumpulan data yang dilakukan dengan cara memberi seperangkat pertanyaan atau pernyataan tertulis kepada responden untuk dijawab (Sugiyono, 2014). Skala Pengukuran untuk semua indikator pada masing-masing variabel dengan menggunakan skala Likert (skala 1 sampai dengan 5) dimulai dari Sangat Tidak Setuju (STS) sampai dengan Sangat Setuju (SS).Skala pengukuran ini berarti bahwa jika nilainya semakin mendekati 1 maka berarti semakin tidak setuju. Sebaliknya, jika semakin mendekati angka 5 berarti semakin setuju. Untuk mengukur kualitas data, dilakukan uji validitas, uji reliabilitas dan uji asumsi klasik. Analisis asosiasi antar variabel dilakukan menggunakan analisis regresi berganda dengan persamaan sebagai berikut:

$$
\mathrm{Y}=\mathrm{a}+b_{1} X_{1}+b_{2} X_{2}+\mathrm{e}
$$

Dimana: $\mathrm{Y}=$ Minat Beli Ulang, $\mathrm{a}=$ Konstanta, $b_{1}-b_{3}=$ Koefisien regresi yang hendak ditaksir, $X_{1}=$ Kualitas Situs Website, $X_{2}=$ Kepercayaan Konsumen, $X_{3}=$ Pengalaman Berbelanja, $\mathrm{e}=$ error $/$ variabel pengganggu

\section{HASIL DAN PEMBAHASAN \\ Profil Responden}

Untuk menggambarkan responden yang menjadi obyek penelitian ini sebagaimana uraian berikut ini: Responden yang berusia 17- 25 tahun sebanyak 76 responden (76\%), responden yang berusia 26 - 35 tahun sebanyak 10 responden $(10 \%)$, responden yang berusia $36-45$ tahun sebanyak 9 responden (9\%) dan responden yang berusia $>46$ tahun sebanyak 5 responden (5\%). ). Hal ini menunjukan bahwa responden yang usia 17-25 tahun merupakan responden yang terbanyak dan diikuti responden $26-35$ tahun diikuti responden $36-45$ tahun, responden berusia $>46$ tahun yang paling sedikit. Berdasarkan
Website and Online Repurchasing Interest

5


Website and

Online Purchasing

Interest

jenis kelamin, responden laki-laki sebanyak 52 responden $(52 \%)$, dan responden perempuan sebanyak 48 responden (48\%), maka jumlah responden Laki-laki lebih mayoritas dibanding responden Perempuan.

Responden yang berstatus sebagai pelajar/mahasiswa 64 orang (64\%), wiraswasta 5 orang (5\%), Karyawan Swasta 15 orang (15\%), PNS 8 orang (8\%), dan Ibu Rumah Tangga 8 orang $(8 \%)$. Hal ini menunjukan bahwa responden Pelajar/mahasiswa terbanyak diikuti karyawan swasta, PNS, ibu rumah tangga , dan wiraswasta yang paling sedikit. Responden berdasarkan penghasilan perbulan $<$ Rp 1.000 .00050 orang $(50 \%)$, responden berdasarkan penghasilan $\mathrm{Rp} 1.000 .000$ - Rp 4.000 .00033 orang (33\%), responden berdasarkan penghasilan $\mathrm{Rp} 5.000 .000$ - Rp 9.000 .00013 orang ( $13 \%$ ) dan responden berdasarkan penghasilan $>\mathrm{Rp} 10.000 .0004$ orang ( $4 \%$ ).

\section{Hasil Uji Kualitas Data}

Berdasarkan hasil uji validitas secara berturut-turut untuk pernyataan 1; 2 dan 3 diperoleh nilai r-product moment hitung sebesar 0,197; 0,887 dan 0,829 lebih besar dari pada r-product moment tabel $(n=98 ; \alpha=5 \%)=0,197$, dan didukung oleh nilai signifikansi yang berada dibawah $5 \%$ dengan demikian seluruh pernyataan pada variabrel X1 (Kualitas Situs Website) dinyatakan valid dan dapat digunakan untuk penelitian selanjutnya. Pernyataan 1; 2 dan 3 varianel Kepercayaan Konsumen diperoleh nilai rproduct moment hitung sebesar 0,795; 0,799 dan 0,776 lebih besar dari pada r-product moment tabel $(n=98 ; \alpha=5 \%)=0,197$, dan didukung oleh nilai signifikansi yang berada dibawah $5 \%$ dengan demikian seluruh pernyataan pada variabrel X2 (Kepercayaan Konsumen) dinyatakan valid dan dapat digunakan untuk penelitian selanjutnya.

Kemudian untuk pernyataan 1; 2 dan 3 variabel PEngalaman Berbelanja diperoleh nilai r-product moment hitung sebesar 0,$832 ; 0,930$ dan 0,908 lebih besar dari pada $\mathrm{r}$ product moment tabel $(n=98 ; \alpha=5 \%)=0,197$, dan didukung oleh nilai signifikansi yang berada dibawah $5 \%$ dengan demikian seluruh pernyataan pada variabrel X3 (Pengalaman Berbelanja) dinyatakan valid dan dapat digunakan untuk penelitian selanjutnya. Pernyataan $1 ; 2 ; 3 ; 4 ; 5 ; 6 ; 7$ dan 8 variabel Minat Beli Ulang diperoleh nilai r-product moment hitung sebesar 0,$774 ; 0,611 ; 0,880 ; 0,762 ; 0,819 ; 0,773 ; 0,592$ dan 0,494 . lebih besar dari pada r-product moment tabel $(n=98 ; \alpha=5 \%)=0,197$, dan didukung oleh nilai signifikansi yang berada dibawah $5 \%$ dengan demikian seluruh pernyataan pada variabrel Y (Minat Beli Ulang) dinyatakan valid dan dapat digunakan untuk penelitian selanjutnya.

Hasil nilai cronbacnh's alpha variable Kualitas Situs Website (x1), Kepercayaan Konsumen (x2), Pengalaman Berbelanja (x3), Minat Beli Ulang (Y) dan gabungan semua variable X1, X2, X3 \& Y lebih besar dari standar reliabilitas sebesar 0,600. Sehingga kuesioner/indikator yang digunakan oleh keempat variable handal atau dapat dipercaya sebagai alat ukur variable yaitu apabila dilakukan pengukuran ulang maka data yang didapat akan konsisten dari waktu ke waktu. Berdasarkan uji normalitas, diketahui bahwa nilai signifiakan sebesar 0,086lebih besar dari 0,05 sehingga dapat disimpulkan bahwa data yang diuji berdistribusi normal. Dari uji multikolinearitas, dapat dilihat nilai tolerance untuk Kualitas Situs Website, Kepercayaan Konsumen dan Pengalaman Berbelanja adalah $0,758,0,458$ dan 0,520 Nilai tolerance di atas 0.1 sehingga dapat disimpulkan bahwa tidak terjadi multikolinearitas antar variabel bebas. Uji multikolinearitas dapat pula dilakukan dengan cara membandingkan VIF (Variance Inflation Factor) di bawah 10. Jika nilai VIF $<10$ maka tidak terjadi. Hasil pengujian varibel bebas VIF untuk Kualitas Situs Website adalah 1,319, Kepercayaan Konsumen adalah 2,182, dan Pengalaman Berbelanja dalah 1,925. Dari hasil pengujian tersebut dapat disimpulkan bahwa tidak terjadi multikolinearitas antar variabel bebas. Dengan demikian uji asumsi klasik tidak adanya multikolinearitas dapat terpenuhi. Berdasarkan hasil pengujian heteroskedastisitas, diketahui bahwa semua variabel independen secara statistik baik X1 (Kualitas Situs Website), X2 (Kepercayaan Konsumen) dan X3 (Pengalaman Berbelanja) mempunyai nilai sig $>0,05$ atau di atas 5\%, maka dapat disimpulkan bahwa tidak terjadi heteroskedastisitas dalam model regresi. 

Dependen

\begin{tabular}{lccc}
\hline \multicolumn{1}{c}{ Keterangan } & Koefisien & $\mathrm{t}_{\text {hitung }}$ & Signifikansi \\
\hline (Konstanta) & 9.236 & 4.073 & 0.000 \\
Kualitas Website & 0.220 & 1.056 & 0.294 \\
Kepercayaan Konsumen & 0.574 & 2.140 & 0.035 \\
Pengalaman Berbelanja & 0.962 & 4.115 & 0.000 \\
R & 0.669 & & \\
R Square & 0.448 & & \\
Adjusted R Square & 0.431 & & 0.000 \\
$F_{\text {hitung }}$ & 25.978 & & \\
\hline
\end{tabular}

Sumber: Data Primer Diolah

Berdasarkan tabel 1 dapat ditentukan persamaan regresi berganda untuk penelitian ini sebagai berikut : $\hat{Y}=9,236+0,220 x_{1}+0,574 x_{2}+0,962 x_{3}+$ error

Dengan demikian dapat dinyatakan bahwa, jika:

a. $\mathrm{X} 1=\mathrm{X} 2=\mathrm{X} 3=0$, maka $\mathrm{Y}$ nilainya sebesar 9,236

b. Jika X1 naik sebesar 1 (satu) satuan maka Y akan naik sebesar 0,220 jika variabel lain dianggap konstan

c. Jika X2 naik sebesar 1 (satu) satuan maka Y akan turun sebesar 0,574 jika variabel lain dianggap konstan

d. Jika X3 naik sebesar 1 (satu) satuan maka Y akan naik sebesar 0,962 jika variabel lain dianggap konstan.

Berdasarkan pada tabel 1, hasil output model summary dapat dijelaskan bahwa hubungan atau korelasi berganda pada seluruh variabel (Kualitas Situs Website, Kepercayaan Konsumen, Pengalaman Berbelanja dan Minat Beli Ulang), memiliki kekuatan hubungan yang rendah. Hal ini dilihat berdasarkan nilai koefisien korelasi berganda sebesar 0,669. Perolehan nilai koefisien determinasi r-square sebesar 0,448 dapat dijelaskan bahwa variabel Kualitas Situs Website, Kepercayaan Konsumen, Pengalaman Berbelanja, dan Minat Beli Ulang mampu mempengaruhi atau menjelaskan keragaman (variabilitas). Nilai dari Minat Beli Ulang sebesar 44,8\% sedangkan sisanya sebesar $(100 \%-44,8 \%=55,2 \%)$ dipengaruhi di luar model atau dijelaskan oleh variabel lain yang tidak diteliti.

\section{Kolerasi Antar Variabel}

Analisis korelasi digunakan untuk melihat adanya hubungan antara variabel Kualitas Situs Website, Kepercayaan Konsumen, Pengalaman Berbelanja dan Minat Beli Ulang serta keeratan hubungannya maka dari itu dilakukan analisis korelasi. Hasil analisis dari korelasi adalah koefisien korelasi yang menunjukkan kekuatan dan kelemahan dari suatu hubungan. Sedangkan untuk membuktikan ada tidaknya pengaruh antar variabel, akan dilakukan analisis regresi secara simultan untuk masing-masing variabel pada masingmasing variabel.

Tabel 2 Korelasi Antar Variabel

\begin{tabular}{lcc}
\hline \multicolumn{1}{c}{ Variabel } & \multicolumn{2}{c}{ Minat Beli Ulang } \\
& Korelasi Pearson & Signifikansi \\
\hline Kualitas Website & 0.370 & 0.000 \\
Kepercayaan Konsumen & 0.584 & 0.000 \\
\hline Pengalaman Berbelanja & 0.633 & 0.000 \\
\hline
\end{tabular}

Sumber: Data Diolah

Berdasarkan Tabel 2, Hasil Uji Korelasi menunjukkan bahwa:

1. Variabel Kualitas Situs Website berkorelasi positif sebesar 0,490 terhadap variabel Kepercayaan Konsumen, dan dapat disimpulkan kedua variabel tersebut terdapat korelasi yang signifikan antara variabel yang dihubungkan, Memiliki hubungan yang Sedang. 
Website and Online Purchasing Interest
2. Variabel Kualitas Situs Website berkorelasi positif sebesar 0,372 terhadap Pengalaman Berbelanja, dan dapat disimpulkan kedua variabel tersebut terdapat korelasi yang signifikan antara variabel yang dihubungkan, Memiliki hubungan yang Rendah.

3. Variabel Kualitas Situs Website berkorelasi positif sebesar 0,370 Terhadap variabel Minat Beli Ulang, dan dapat disimpulkan kedua variabel tersebut terdapat korelasi yang signifikan antara variabel yang dihubungkan, Memiliki hubungan yang Rendah.

4. Variabel Kepercayaan Konsumen berkorelasi positif sebesar 0,692 terhadap variabel Pengalaman Berbelanja, dan dapat disimpulkan kedua variabel tersebut terdapat korelasi yang signifikan antara variabel yang dihubungkan, Memiliki hubungan yang Kuat.

5. Variabel Kepercayaan Konsumen berkorelasi positif sebesar 0,584 terhadap Minat Beli Ulang, dan dapat disimpulkan kedua variabel tersebut terdapat korelasi yang signifikan antara variabel yang dihubungkan, Memiliki hubungan yang Sedang.

6. Variabel Pengalaman Berbelanja berkorelasi positif sebesar 0,633 terhadap variabel Minat Beli Ulang, dan dapat disimpulkan kedua variabel tersebut terdapat korelasi yang signifikan antara variabel yang dihubungkan, Memiliki hubungan yang Kuat.

\section{Uji Hipotesis Statistik}

Untuk menunjukan hubungan Kualitas Situs Website (X1) dengan Minat Beli Ulang (Y), Kepercayaan Konsumen (X2) dengan Minat Beli Ulang (Y), Pengalaman Berbelanja (X3) dengan Minat Beli Ulang (Y) dengan $\propto=5 \%(\mathrm{df}=\mathrm{n}-\mathrm{k}-1$ atau $\mathrm{df}=100-3-1=96$; $\alpha=5 \%)=1,96$. maka:

1. Hipotesis pengujian antara $\mathrm{X} 1$ terhadap $\mathrm{Y}$ secara parsial

Ho : $\beta=0$, tidak terdapat pengaruh antara Kualitas Situs Website terhadap Minat Beli Ulang.

H1 : $\beta>0$, terdapat pengaruh antara Kualitas Situs Website terhadap Minat Beli Ulang.

Berdasarkan tabel 1 diperoleh nilai t hitung sebesar 1,056 dan $t$ tabel sebesar 1,96 dengan demikian maka $t$ hitung lebih kecil dari t tabel atau $(1,056<1,96)$. Dengan demikian hipotesis satu ditolak, H0 diterima dan H1 ditolak hal ini berarti terdapat hubungan yang negatif dan tidak signifikan antara Kualitas Situs Website dengan Minat Beli Ulang.

2. Hipotesis pengujian antara $\mathrm{X} 2$ terhadap $Y$ secara parsial

Ho : $\beta=0$, tidak terdapat pengaruh antara Kepercayaan Konsumen dengan Minat Beli Ulang.

$\mathrm{H} 2: \beta \neq 0$, terdapat pengaruh Desain Produk dengan Keputusan Pembelian.

Berdasarkan tabel 1 diperoleh nilai t hitung sebesar 2,140 dan t tabel sebesar 1,96 dengan demikian maka $t$ hitung lebih besar dari t tabel atau $(2,140>1,96)$. Dengan demikian hipotesis dua diterima, $\mathrm{H} 0$ ditolak dan $\mathrm{H} 2$ diterima hal ini berarti terdapat hubungan positif dan signifikan antara Kepercayaan Konsumen dengan Minat Beli Ulang.

3. Hipotesis pengujian antara $\mathrm{X} 3$ terhadap $\mathrm{Y}$ secara parsial

Ho : $\beta=0$, tidak terdapat pengaruh antara Pengalaman Berbelanja dengan Minat Beli Ulang.

H3 : $\beta \neq 0$, terdapat pengaruh antara Pengalaman Berbelanja dengan Minat Beli Ulang.

Berdasarkan tabel 1 diperoleh nilai t hitung sebesar 4,115 dan $\mathrm{t}$ tabel sebesar 1,96 dengan demikian maka $t$ hitung lebih besar dari t tabel atau $(4,115>1,96)$. Dengan demikian hipotesis tiga diterima, $\mathrm{H} 0$ ditolak dan $\mathrm{H} 3$ diterima hal ini berarti ada hubungan yang positif dan signifikan antara Pengalaman Berbelanja dengan Minat Beli Ulang.

4. Hipotesis pengujian antara $\mathrm{X} 1, \mathrm{X} 2$ dan $\mathrm{X} 3$ terhadap $\mathrm{Y}$ secara simultan H0: $\beta=0$ Tidak terdapat pengaruh antara Kualitas Situs Webiste, Kepercayaan Konsumen dan Pengalaman Berbelanja dengan Minat Beli Ulang. 
H1: $\beta \neq 0$ Terdapat pengaruh antara Kualitas Situs Website, Kepercayaan Konsumen dan Pengalaman Berbelanja dengan Minat Beli Ulang.

Berdasarkan tabel 1 diperoleh nilai $\mathrm{F}$ hitung sebesar 25,978 dan $\mathrm{F}$ tabel sebesar 2,70 dengan demikian maka $F$ hitung lebih besar dari $F$ tabel atau $(25,978>2,70)$. Dengan demikian hipotesis pertama diterima, $\mathrm{H} 0$ ditolak dan $\mathrm{H} 1$ diterima hal ini berarti ada hubungan yang signifikan antara Kualitas Situs Website, Kepercayaan Konsumen dan Pengalaman Berbelanja dengan Minat Beli Ulang di Situs Jual Beli Online OLX.

\section{Pembahasan}

Pengaruh antara Kualitas Situs Website (X1) dengan Minat Beli Ulang (Y). Berdasarkan hasil yang menyatakan bahwa Kualitas Situs Website mempunyai hubungan yang negatif tehadap Minat Beli Ulang dinyatakan ditolak, Habibi et al (2014), website quality adalah ukuran keunggulan website, berdasarkan evaluasi pengguna pada fitur dalam memenuhi kebutuhan pelanggan. Implikasi Manajerial : Pihak manajemen harus bisa menciptakan kualitas wesbite yang lebin menarik dan memudahkan konsumen. Situs Website OLX perlu melakukan pembaruan pada notifikasi situs website OLX untuk mempermudah konsumen mendapatan notifikasi yang up to date dari OLX, karena Kualitas Situs Website terbukti tidak berpengaruh dan tidak signifikan terhadap Minat Beli Ulang.

Pengaruh antara Kepercayaan Konsumen (X2) dengan Minat Beli Ulang (Y). Berdasarkan hasil yang menyatakan bahwa Kepercayaan Konsumen berpengaruh secara positif dan namun tidak signifikan terhadap Minat Beli ulang dinyatakan diterima, penelitian ini membuktikan teori yang disampaikan oleh Menurut Sunarto (2009) Kepercayaan konsumen (Consumen Beliefs) adalah semua pengetahuan yang dimiliki konsumen dan semua kesimpulan yang dibuat konsumen tentang objek, atribut, dan manfaatnya. Objek (Objects) dapat berupa produk, orang, perusahaan, dan segala sesuatu, dimana seseorang memiliki kepercayaan dan sikap. Sedangkan atribut (Attributes) adalah karakteristik atau fitur yang mungkin dimiliki atau tidak dimiliki oleh objek. Sedangkan manfaat (Benefits) adalah hasil positif yang diberikan atribut kepada konsumen. Para manager harus menyadari bahwa kepercayaan terhadap objek, atribut, dan manfaat menunjukan presepsi konsumen, dan karena itu umumnya kepercayaan seorang konsumen berbeda dengan konsumen lainnya. Kemudian Penlitian ini mendukung penelitian dari Nurul Azifah, Citra Kusuma Dewi (2016) yang menunjukan bahwa Kepercayaan Konsumen berpengaruh positif dan tidak signifikan terhadap Niat Pembelian Online. Implikasi Manajerial : Situs Website OLX perlu menjaga kepercayaan dari para pelanggan, karena merupakan suatu keharusan bagi sebuah toko online, oleh karena itu Website OLX harus menyediakan informasi mengenai produk/jasa dengan jelas dan tidak dibuat - buat, karena kepercayaan sudah terbukti berpengaruh dan tidak signifikan terhadap Minat Beli Ulang

Pengaruh antara Pengalaman Berbelanja (X3) dengan Minat Beli Ulang (Y). Berdasarkan hasil yang menyatakan bahwa Pengalaman Berbelanja berpengaruh secara positif dan signifikan terhadap Minat Beli ulang dinyatakan diterima, penelitian ini membuktikan teori yang disampaikan oleh Ling (2010) dalam bukunya menjelaskan, pengalaman sebelumnya akan sangat mempengaruhi perilaku masa depan. Pelanggan juga ingin perusahaan-perusahaan dan merek-merek tersebut dapat berhubungan dengan hidup mereka, mengerti mereka, menyesuaikan dengan kebutuhan mereka dan membuat hidup mereka lebih terpenuhi. Dalam era informasi, teknologi, perubahan dan pilihan, setiap perusahaan perlu lebih selaras dengan pelanggan dan pengalaman yang diberikan produk atau jasa mereka. Kemudian penlitian ini mendukung penelitian dari Ikranegara (2017) yang menunjukan bahwa Pengalaman Berbelanja berpengaruh positif dan signifikan terhadap Minat Beli Secara Online.. Implikasi Manajerial : Situs Website OLX harus memberikan pelayan yang terbaik untuk konsumen selama berbelanja online disitus Webite OLX, karena pengalaman berbelanja sudah terbukti berpengaruh dan signifikan terhadap Minat Beli Ulang.
Website and Online Repurchasing Interest

9


Website and

Online Purchasing

Interest

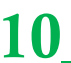

Pengaruh antara Kualitas Situs Website (X1), Kepercayaan Konsumen (X2), dan Pengalaman Berbelanja (X3) dengan Minat Beli Ulang (Y). Berdasarkan hasil yang menyatakan Kualitas Situs Website, Kepercayaan Konsumen, dan Pengalaman Berbelanja positif secara bersama-sama Minat Beli Ulang. Berdasarkan hasil uji $\mathrm{F}$ atau pengujian simultan, $\mathrm{F}$ hitung adalah sebesar 25.978 dan lebih besar dari $\mathrm{F}$ tabel ( $\alpha=5 \%$, $\mathrm{df} 1=3, \mathrm{df} 2=96.)=2,70$ dan didukung oleh nilai signifikan sebesar 0,000 dan lebih kecil dari $(\alpha=5 \%)=0,05$ dengan demikian dari hasil tersebut dapat disimpulkan hipotesis diterima karena terdapat hubungan yang positif dan signifikan antara Kualitas Situs Website, Kepercayaan Konsumen, dan Pengalaman Berbelanja Terhadap Minat Beli Ulang.

\section{PENUTUP}

Berdasarkan hasil analisis dan pembahasan yang telah diuraikan sebelumnya, maka dapat ditarik beberapa kesimpulan dari keseluruhan hasil penelitian yaitu sebagai berikut :

a. Kualitas Situs Website tidak berpengaruh positif dan tidak signifikan terhadap minat beli ulang di situs jual beli online OLX. Berdasarkan hasil pengujian parsial yang diperoleh atas variabel Kualitas Situs Website maka $\mathrm{T}$ - hitung lebih kecil dari $\mathrm{T}-$ tabel $(1,056<1,96)$, pada pengguna Situs Jual Beli Online OLX di Kota Bogor.

b. Kepercayaan konsumen memiliki pengaruh positif dan signifikan terhadap minat beli ulang di situs jual beli online OLX. Berdasarkan hasil pengujian parsial yang diperoleh atas variabel kepercayaan konsumen dengan demikian maka $\mathrm{T}$ - hitung lebih besar dari T - tabel $(2,140>1,96)$, pada pengguna situs jual beli online OLX di Kota Bogor.

c. Pengalaman berbelanja memiliki pengaruh yang positif dan signifikan terhadap minat beli ulang di situs jual beli online OLX. Berdasarkan hasil pengujian parsial yang diperoleh atas variabel Pengalaman Berbelanja sebesar dengan demikian maka $\mathrm{T}$ hitung lebih besar dari T - tabel $(4115>1,96)$, pada pengguna situs jual beli online OLX di Kota Bogor.

d. Kualitas Situs Website, Kepercayaan Konsumen dan Pengalaman Berbelanja secara bersama-sama memiliki pengaruh yang positif dan signifikan terhadap Minat Beli Ulang di Situs Jual Beli Online OLX. Berdasarkan hasil pengujian simultan, F-hitung $>$ F-tabel pada pengguna situs jual beli online OLX di Kota Bogor.

\section{DAFTAR PUSTAKA}

[1]. Arikunto, S. 2005. Manajemen Penelitian. Yogyakarta: Rineka Cipta

[2]. Augusty, Ferdinand. 2011, Metode Penelitian Manajemen Pedoman Penelitian untuk Penulisan Skripsi, Tesis, dan Disertasi Ilmu Manajemen, Edisi 3, AGF Books, Fakultas Ekonomika dan Bisnis Universitas Diponegoro, Semarang.

[3]. Andi, Sunarto. 2009. Seluk Beluk E-Commerce. Graha Ilmu. Yogyakarta.

[4]. Ang,L., Dubelaar, C., and Lee B. 2009 To turst or not trust? A model trust from the customers's pont of view. In Proceedings of the 14th Bled Electronic Commerce Confrence, Bled, Slovenia 25-26 June 2001

[5]. Barnes, S., \& Vidgen, R. 2003. Measuring Web Site Quality Improvements: A Case Study of the Forum on Strategic Management Knowledge Exchange. Industrial Management \& Data Systems

[6]. Dharmmesta, Basu Swastha dan T. Hani Handoko. 2012. Manajemen Pemasaran. Edisi Pertama Cetakan Kelima. Yogyakarta: BPFE

[7]. Gefen, David. 2003. Trust and Tam in Online Shopping: An Integrated Model. MIS Quarterty. March 51-90.

[8]. Ghozali, Imam. 2013. Aplikasi Analisis Multivariate dengan Program SPSS. Edisi Ketujuh. Semarang : Badan Penerbit Universitas Diponegoro.

[9]. Indrajit, Richardus Eko. 2002. Electronic Government:Strategi Pembangunan dan Pengembangan Sistem Pelayanan Publik Berbasis Teknologi Digital. Andi. Yogyakarta. 
[10]. Jasfar, F. 2009. Manajemen Jasa Pendekatan Terpadu. Jakarta Penerbit : Ghalia Indonesia.

[11]. Kotler, Philip.2009. Manajemen Pemasaran, Jilid I dan II, Edisi Kesebelas, PT. Indeks, Gramedia, Jakarta

[12]. Peter J.Paul dan Olson Jerry C. 2007. Consumer Behavior and Marketing Strategy. Jilid1.8. United States : McGraw Hill Higher Education

[13]. Riduwan. 2010. Skala Pengukuran Variabel Variabel Penelitian. Bandung: Alfabeta.

[14]. Santoso, Singgih. 2010. Statistik Parametrik, Konsep dan Aplikasi dengan SPSS. Cetakan Pertama, PT Elex Media Komputindo, Jakarta, PT Gramedia, Jakarta.

[15]. Schiffman, Leon, L. Lazar Kanuk. 2008. Perilaku Konsumen. Alih Bahasa : Zoelkifli Kasip. Jakarta : PT. INDEKS

[16]. Simamora, Bilson. 2008. Panduan Riset Perilaku Konsumen, PT Gramedia Pustaka Utama. Jakarta

[17]. Sugiyono. 2014. Metode Penelitian Kuantitatif Kualitatif dan R\&D. Bandung:CV. Alfabeta.

[18]. Sunyoto, Danang. 2014. Konsep Dasar Riset Pemasaran \& Perilaku Konsumen. Yogyakarta : CAPS

[19]. Sumarwan, Ujang. 2011. Perilaku Konsumen Teori dan Penerapannya Dalam Pemasaran. Bogor Penerbit: Ghalia Indonesia.

[20]. Sumarwan, Ujang. 2014. Perilaku konsumen: teori dan penerapanya dalam pemasaran. Jakarta: PT. Ghalia Indonesia

[21]. Usman, Husaini, 2013, Manajemen (Teori, Praktik, dan Riset Pendidikan), Edisi Keempat, penerbit Bumi Aksara.

[22]. Broutsou, A. 2012, Online Trust: The Influence of Perceived Company's Reputation on Consumers' Trust and the Effects of Trust on Intention for Online Transactions, Journal of Service Science and Management, 2012, 5, 365-372.

[23]. Chang, H. H., \& Chen, S. W. 2008. The Impact of Customer Interface Quality, Satisfaction and Switching Costs on E-Loyalty: Internet Experience as a Moderator. Computers in Human Behavior, 1016 (10).

[24]. Christina. 2012. Faktor-faktor yang Mempengaruhi Minat Beli di Online Shop Specialis Guess. Jurnal penelitian Volume 7, No 2.

[25]. Habibi, A., Hagh, S. G., Bahabadi, M. H., Hamedani, S. S., Yasin, N. M., dan Omar, N. A., (2014), "Brand Personality Moderating Effect on Relationship Between Website Quality and Online Trust," Malaysian online environment context. Asian Social Science, 10 (11), 210-224.

[26]. Liang, Chiung-Ju, dan Chen, Hui-Ju. 2009. A Study of The Impacts of Website Quality On Customer relationship Performance. Total Quality Management. Vol. 20, No. 9, pp.971-988.

[27]. Lin. 2007. The Effect of Brand Image and Product Knowledge on Purchase Intention Moderated by Price Discount. Journal of International Management Studies

[28]. Ling., Kwek Choon 2010. The Effects of Shopping Orientations, Online Trust and Prior Online Purchase Experience toward Customers' Online Purchase Intention. Vol 3. International Business Research. Malaysia

[29]. Mulyana, M., 2012. Consumer Behaviour: Sukses Dengan Memahami Konsumen.

[30]. Pavlou, Paul A. 2003. "Consumer Acceptance of Electronic Commerce: Integrating Trust and Risk with the Technology Acceptance Model". International Journal of Electronic Commerce, Spring 101-134.

[31]. Schmitt, Brend 2010. Experience Marketing: Concepts, Frameworks and Consumer Inshight. Foundations and Trends in Marketing, Vol.5.No.2 (2010)pp.55-112

[32]. Suhari, Yohanis, 2011. Kepercayaan Terhadap Internet serta pengaruhnya pada Pencarian Informasi dan keinginan Membeli secara Online. Jurnal Dinamika Informatika Vol 3 No. 1 
Website and Online Purchasing Interest
[33]. Wakefield , R. J., M. H., \& Wilder W. M, 2004. The Role Of Web Site Characteristics In Initial Trust Formation. Journal Of Computer Information System, 45 (1), 94-103

[34]. Zhou, T. 2009. The relative importance of website design quality and service quality in determining consumers' online repurchase behavior. Information Systems Management, 26(4), 327-337.

[35]. Azifah, Nurul., Dewi, Citra Kusuma .2016. "Pengaruh Shoping Orientation, Online Trust dan Prior Online Purchase Experience terhadap Online Purchase Intenton (Studi pada Onlineshop Hijabi House)". Fakultas Komunikasi dan Bisnis, Universitas Telkom. Bandung

[36]. Aryanti, Tuti. 2011. "Analisis Perilaku Konsumen Dalam Pemilihan Tempat Belanja Dengan Pendekatan Analytical Hierarchy Process (Studi Kasus Pada Masyarakat Kota Depok)". Fakultas Ekonomi Gunadarma. Depok

[37]. Akbar, Mochamad J. 2014."Analisis Anteseden Preferensi Pembelian Online di Indonesia (Studi Pada Pembeli Online di Kota Semarang)". Universitas Diponegoro, Semarang

[38]. Faradila, Rr. Selli Nisrina,. Soesanto, Harry. 2016. "Analisis Pengaruh Persepsi Kemudahan Pengguna dan Persepsi Manfaat terhadap Minat Beli dengan Kepercayaan Sebagai Variable Intervening (Studi pada pengunjung toko online berrybenka.com dikalangan mahasiswa Universitas Diponegoro)". Fakultas Ekonomi Universitas Diponegoro. Semarang

[39]. Hildaria, Helena. 2017. "Pengaruh Kepercayaan Konsumen, Pengalaman Berbelanja, dan Kemudahan Transaksi Terhadap Minat Belanja Online di Kalangan Mahasiswa". Program Studi Manajemen Universitas Sanata Dharma Yogyakarta

[40]. Ikranegara, Dikla Purbayudya, 2017. "Pengaruh Orientasi Belanja, Kepercayaan Online, dan Pengalaman Pembelian Terhadap Minat Beli Secara Online (Studi Kasus Pada Toko Online Bukalapak)". Fakultas Ekonomi. Universitas Negeri Yogyakarta. Yogyakarta

[41]. Juanda,. Sari. 2014. "Pengaruh Kualitas Webiste Terhadap Repurchase Intention Yang Dimediasi Oleh Kepercayaan Pelanggan (Studi Pada Pelanggan Online Shop Instagram di Kota Malang)". Fakultas Ekonomi dan Bisnis Universitas Muhammadyah Malang. Malang.

[42]. Oetomo, Rahadian Ali. 2012. "Analisis Pengaruh Keragaman Menu, Prespsi Harga dan Lokasi Terhadap Minat Beli Ulang Konsumen (Studi pada Restoran Waroeng Taman Singosari Semarang)". Fakultas Ekonomika dan Bisnis. Universitas Diponegoro Semarang

[43]. Pamungkas, Yustinus Frandhi Cahyo. 2014. "Pengaruh Orientasi Pembelian, Kepercayaan, Dan Pengalaman Pembelian Online Terhadap Minat Beli Online". Skripsi. Fakultas Ekonomi Universitas Negeri Yogyakarta, Yogyakarta

[44]. Tika Dian. 2014. "Pengaruh Harga, Promosi, Kualitas Produk, dan Kepercayaan (Trust) Terhadap Minat Beli K-pop (Korean Pop) Album Dengan Sistem Preorder secara Online". Fakultas Ekonomi Universitas Diponegoro. Semarang

[45]. Wijaya, Petra Surya Mega. 2012. "Faktor-Faktor Yang Mempengaruhi Minat Beli Di Online Shop Specialis Guess". Fakultas Bisnis Universitas Kristen Duta Wacana. Yogyakarta

[46]. Yolandasari, Ni Luh Dian. 2028. "Pengaruh Pengalaman Pelanggan Dan Kepercayaan Terhadap Niat Beli Ulang Secara Online Melalui Kepuasan Pelanggan (Studi Pada Situs Online Berrybenka.com)." Fakultas Ekonomi dan Bisnis Universitas Udayana. Bali

[47]. Yuliandi. (2012) "Pengaruh Kualitas Website Terhadap Minat Beli Produk Jaben Bandung". 